\title{
Uma arqueologia da memória Social
}

\section{An archeology of social memory}

\author{
Gilvando Sá Leitão Rios ${ }^{1}$
}

MARTINS, José de Souza. Uma arqueologia da memória social: autobiografia de um moleque de fábrica. Cotia: Ateliê, 2011.

Um livro impactante este de memória social de José de Souza Martins. De uma obra marcante na área de ciências sociais espera-se que apresente ao menos duas qualidades, uma de ordem teórica, em termos de análises finas e interpretações inovadoras e outra de caráter empírico no sentido de apresentação de dados surpreendentes em termos de desvelamento e de fontes. Esta obra é rica nesses dois aspectos, entretanto a mesma apresenta ainda uma terceira característica, não muito comum, que é a de um estilo que foge ao caráter sisudo, bem ao estilo acadêmico. Encanta pois como uma autêntica peça literária, parece se estar lendo Mario Vargas Llosa, José Saramago ou Graciliano Ramos, não só pelo tom de narrativa, mas sobretudo narrativa não linear, colocando o leitor diante do inesperado e chocante, o autor sempre pegando o leitor de surpresa, a narrativa literalmente surpreende, como os fatos e desventuras da vida. "A memória é, na base, uma memória de surpresas e espantos. A memória não é calma lembrança. È também luta, tensão, sofrimento." (MARTINS, 2011, p. 460). A estrutura do livro já expõe essa originalidade que o sumário contém justamente mas não revela de imediato.

O livro é um tesouro como depoimento, não de um indivíduo, nem mesmo sobre uma família mas de toda a constelação de uma época onde os indivíduos e as famílias são estrelas que apenas a olho nu brilhariam mais ou menos ou mesmo seriam invisíveis, mas cuja realidade é aclarada, desvendada, desnudada por um expor sociologicamente corajoso que joga nas trevas os preconceitos, cambiantes mas constantes, do senso comum. É a aplicação mais acabada do conceito de reflexividade de Bourdieu e Wacquant $(1992)^{2}$ como auto-análise sociológica. A questão da memória é uma questão apaixonante, tanto pelo tratamento abrangente em termos do

\footnotetext{
${ }^{1}$ Doutor em sociologia, pesquisas sobre cooperativismo e políticas públicas de transportes (Departamento de Ciências Sociais da UFRPE)-e-mail: gilvando.rios@hotmail.com

2 Segundo este autor adotar o ponto de vista da reflexividade não implica em renunciar à objetividade, mas sim em questionar o privilégio do sujeito "puramente noético" que escaparia ao trabalho de objetivação, pois "contrariamente à representação comum do conhecimento de si próprio como exploração de singularidades profundas, a verdade mais íntima do que nós somos, o impensado mais impensável, está também inscrito na objetividade, na história das posições sociais que tivemos no passado e que ocupamos no presente.” (BOURDIEU; WACQUANT, 1992, p. 184, tradução livre).
} 
vínculo indissolúvel entre indivíduo e sociedade, como em termos da tessitura inconsútil alinhavada entre passados brumosos e presentes opacos.

O grande interesse desta obra reside sobretudo no seu aspecto metodologicamente criador. Ao contrário de Bourdieu (2005, p. 35) que declara no seu Esboço de autoanálise "isto não é uma autobiografia", Martins assume já no subtítulo a "autobiografia de um moleque de fábrica". Apesar de escolhas aparentemente opostas, ambos estão bem afinados metodologicamente. Para Martins (2011, p. 450) "é uma falsa pressuposição a de que uma biografia é o cumprimento de um destino inexorável [...] o começo e os passos da vida são um conjunto grande de incertezas e acasos". Ora, o autor de $A$ ilusão biográfica (BOURDIEU, 2002, p. 189) assinala semelhantemente que não se pode "tentar compreender uma vida como uma série única e por si suficiente de acontecimentos sucessivos, sem outro vínculo que não a associação a um 'sujeito"'. Ambos os autores buscam capturar o indivíduo nos processos sociais no sentido que lhes dá Elias (2006, p.27-28) de "transformações amplas, contínuas, de longa duração - ou seja, em geral não aquém de três gerações - de figurações formadas por seres humanos, ou de seus aspectos, em uma de duas direções opostas. Uma delas tem, geralmente, o caráter de uma ascensão, a outra o caráter de um declínio." Expressivamente Martins (2011, p. 99) constata num desabafo de denúncia: "Somente a partir dos últimos descendentes de terceira geração de meus avós a condição social de membros da minha família começou a mudar e a mudança só se consolidou na quinta geração, quase um século depois da chegada ao Brasil. Todos os membros dessas cinco gerações trabalharam desde quando eram crianças, homens e mulheres, na roça ou na fábrica. Uma verdadeira servidão nessa demorada transição pelos meandros atrasados do capitalismo e da acumulação primitiva em direção ao mundo moderno. Tardio desembarque no porto da modernidade, por longo tempo apenas vista de longe." Ambos os autores pois buscam situar o indivíduo contextualizado à luz da teoria social. Bourdieu (2005, p. 39) declara: "nesse esforço para explicar-me e compreender-me, poderei doravante apoiar-me nos cacos de objetivação de mim mesmo que fui deixando pelo caminho, ao longo de minha pesquisa, e tentarei aqui aprofundar e ainda sistematizar." Martins (2011, p. 460) por seu turno ao narrar suas lembranças de criança e seu ingresso penoso e precoce no mundo do trabalho, rural e urbano, informal e formal, procura "descobrir nelas a coerência que a sociologia oferece como instrumento interpretativo que torna compreensível o que não teve sentido no seu próprio momento." Uma frase resume bem a perspectiva metodológica do autor em termos de abarcar simultaneamente a subjetividade individual e os condicionamentos objetivos: "Só a consciência crítica do ver-se, reconhecer-se e aceitar-se [...] pode revelar o que a sociedade efetivamente é e o que nela somos como individualidades. Esse é o percurso deste livro." (MARTINS, 2011, p. 452).

Fazendo sociologia da sociologia o autor fundamenta teoricamente seu interesse pelo tema da memória partindo do fato que a consciência moderna e portanto "urbana e de elite, é a consciência da negação plena e absoluta do passado." (MARTINS, 2011, p. 184). Ora, esse desprezo do senso comum moderno pelo passado, como refugo, teria condicionado então a própria Sociologia, ${ }^{3}$ a qual como "fruto do urbano e do moderno, trata o passado como persistência indesejada quando isso ocorre, como perturbação do curso da sociedade, como anomia e como problema social." (MARTINS, 2011, p. 184). Para o autor a Sociologia teria consagrado este ponto de vista empobrecendo a análise de uma

\footnotetext{
O autor escreve Sociologia com maiúscula querendo com isto identificar o produto histórico-cultural, campo social na acepção que lhe dá Bourdieu (1983, 2004). Já sociologia com minúscula indicaria as virtualidades do método.
} 
sociedade como a nossa, "marcada fortemente pela persistência de relações sociais e de concepções antigas, pela coexistência de tempos de diferentes datações." (MARTINS, 2011, p. 184). Esta oposição absoluta entre passado e presente já fora criticada por Elias (2006, p. 209) pelo fato de "a sociologia ter se tornado, cada vez mais, um domínio de pesquisa relacionado ao presente, e a história, por sua vez, ao passado; este tipo de separação proporcionada pela divisão do trabalho além disso, tem alimentado a tendência a igualar o "histórico" a algo relacionado ao passado e o "sociológico" a algo relacionado ao presente e, conseqüentemente, a pensar o "presente" e o "passado" das sociedades humanas como se tivessem em si mesmos uma existência separada e independente."

Um aspecto que a meu ver merece destaque em Uma arqueologia da memória social é que a questão da memória individual não se descola do contexto coletivo mas ambos se fundem dialeticamente. "A memória nos diz que cada um de nós é o encontro de muitos. São os momentos em que podemos nos ver e nos reconhecer diante do espelho das lembranças, no modo de ser dos outros." (MARTINS, 2011, p. 444). Noutro trecho marcante o autor destaca o paradoxo existencial dos muitos "eus" que vivenciamos nas nossas biografias em função das conexões coletivas. "A memória é a sua própria circunstância. A memória dos que viveram transições sociais e históricas acaba sendo a memória dos muitos eus que cada um é, as diversas vidas que ganhamos, mas também as várias mortes que sofremos com o passar do tempo.” (MARTINS, 2011, p. 447). Uma frase-síntese exprime bem esta visão dialética da memória: "A história de muitos [...] se sumariza na biografia de cada um de nós" (MARTINS, 2011, p. 440). Face à morte sociológica que nos é imposta recorrentemente pelas transformações sociais contemporâneas nos surpreende o autor: "A memória é uma ressurreição.” (MARTINS, 2011, p. 462).

\section{Referências}

BOURDIEU, P. A ilusão biográfica. In: AMADO, J.; FERREIRA, M. de M. (Org.). Usos e abusos da história oral. Rio de Janeiro: FGV, 2002. p. 183-191. . Coisas ditas. São Paulo: Brasiliense, 2004. . Esboço de autoanálise. São Paulo: Companhia das Letras, 2005.

Zero, 1983.

Questões de sociologia. Rio de Janeiro: Marco

BOURDIEU, P.; WACQUANT, L. J. D. Réponses. Paris: Seuil, 1992.

ELIAS, N. Escritos \& ensaios 1 estado, processo, opinião pública. Rio de Janeiro: Zahar, 2006.
Recebido em: maio de 2011 Aceito em: junho de 2011 